\title{
Chronic Prostatitis / Chronic Pelvic Pain Syndrome
}

\author{
Nikhil Vasdev and Andrew C Thorpe \\ Department of Urology, Freeman Hospital, Newcastle upon Tyne \\ UK
}

\section{Introduction}

Chronic prostatitis (CP) refers to "inflammation" of the prostate and is thought to be related to either an acute or chronic infection of the prostate gland. It is important to distinguish chronic prostatitis / chronic pelvic pain syndrome (CPPS) from other forms of infections of the prostate gland which include chronic bacterial prostatitis and acute bacterial prostatitis [1]. The aetiology, pathogenesis, and optimal treatment of $\mathrm{CP} / \mathrm{CPPS}$ continue to be evaluated. In addition to an infective and inflammatory pathogenesis hypothesized for patients with CP/CPPS, it is important to highlight a variable degree of neuropathic pain. We present the current definition, pathogenesis and new treatment methodologies being developed to treat CP/CPPS, which continue to be a challenging clinical entity to treat worldwide by Urologist.

\section{Definition and classification}

The European Urology Association [EAU] 2010 guidelines use the term "Painful Prostate Syndrome (PPS)" instead of the initial terminology by the National Institute of Diabetes and Digestive and Kidney Diseases (NIDDK) of CP/CPPS. PPS or CP/CPSS is defined as PPS is persistent discomfort or pain in the pelvic region with sterile specimen cultures and either significant or insignificant white blood cell counts in prostate-specific specimens (i.e., semen, expressed prostatic secretions, and urine collected after prostate massage) [2]. As there are no clinically relevant diagnostic or therapeutic consequences arising from differentiating between inflammatory and noninflammatory subtypes, $\mathrm{CP} / \mathrm{CPPS}$ can be regarded as one entity.

The National Institute of Health (NIH) International Collaborative Prostatitis Network developed a prostatitis classification system in 1995, which termed CP/CPPS as 'Category III prostatitis' defined by its abacterial nature and occurrence with or without prostatic inflammation [3, 4]. A summary of this classification is presented in Table 1.

As per the NIH classification in actual clinical practice, both Type I (Acute Bacterial Prostatitis) and Type II (Chronic Bacterial Prostatitis) only account for approximately 5-10\% of patients [5]. Acute prostatitis is characterized by a sudden onset of fever and dysuria. Chronic prostatitis is clinically characterized by recurrent episodes associated with recurrent same organism. Patients tend to be asymptomatic in-between episodes of infections. 


\begin{tabular}{|l|l|l|}
\hline NIH Consensus & Clinical descriptor & Clinical details \\
\hline Type I & $\begin{array}{l}\text { Acute bacterial } \\
\text { prostatitis }\end{array}$ & $\begin{array}{l}\text { Severe symptoms of prostatitis, } \\
\text { symptoms of systemic infection and } \\
\text { acute bacterial urinary tract infection } \\
\text { with bacteriuria and pyuria }\end{array}$ \\
\hline Type II & $\begin{array}{l}\text { Chronic bacterial } \\
\text { prostatitis }\end{array}$ & $\begin{array}{l}\text { Chronic bacterial infection of the } \\
\text { prostate gland with or without } \\
\text { symptoms of prostatitis, usually with } \\
\text { recurrent UTI's cause by the same } \\
\text { bacteria }\end{array}$ \\
\hline Type III A & $\begin{array}{l}\text { Characterized by chronic pelvic pain } \\
\text { and possibly voiding symptoms with } \\
\text { no bacterial infection; leucocytes } \\
\text { present in expressed prostatic } \\
\text { secretions or semen }\end{array}$ \\
\hline Type III B & $\begin{array}{l}\text { CP/CPPS) } \\
\text { and possibly voiding symptoms with } \\
\text { no bacterial infection; leukocytes } \\
\text { present in expressed prostatic } \\
\text { secretion or semen }\end{array}$ \\
\hline Type IV & $\begin{array}{l}\text { Non-Inflammatory } \\
\text { subtype }\end{array}$ & $\begin{array}{l}\text { Evidence of inflammation without } \\
\text { symptoms of prostatitis or UTI }\end{array}$ \\
\hline aWBC semen $>10^{6} / \mathrm{ml}$, WBC EPS $>5$ p hpf, WBC VB3 $>10$ p hpf \\
\hline
\end{tabular}

Table 1. NIH classification of prostatitis syndromes.

Type III is classified as CP/CPPS and PPS as per the latest EAU guidelines. Patients within this category constitute about $90 \%$ of cases and it is hence very important to understand the definition of Type IIIA and Type IIIB categories. Type IIIA refers to the presence of white blood cells (WBC) in semen, after a prostate massage urine specimen (VB3) or expressed prostatic secretion (EPS). Type IIIB refers to patients with pelvic pain with no evidence of inflammation on semen, VB3 or EPS.

Type IV patients are asymptomatic and are commonly diagnosed during work up for infertility and lower urinary tract symptoms (LUTS) where they have an elevated PSA. In the MTOPS study, there is a strong link between prostatic inflammation to increased LUTS or the risk of acute urinary retention in a cohort of BPH subjects [6]. This may suggest that Type IV prostatitis may not be "asymptomatic" after all.

\section{Epidemiology}

Prostatitis is a significant health problem with prevalence rates of $11-16 \% .[7,8]$ More than 2 million consultations for prostatitis are required every year in the United States[9]. Prostatitis has a significant impact on the quality of life (QoL) comparable to active Crohn's disease or a recent myocardial infarction.[10] with up to $50 \%$ of men affected by it at some stage of their lives.[11,12].

In a large recent review by Krieger et al [13], the prevalence of prostatitis symptoms in 10,617 men was $8.2 \%$ (873). Amongst these patients the prevalence of prostatitis symptoms ranged from $2.2 \%$ to $9.7 \%$, with a median rate of $8.7 \%$. 
Prostatitis-like symptoms result in a substantial number of physician visits. Sixty percent of participants with prostatitis-like symptoms seek medical help [13, 14]. The odds of a prostatitis diagnosis is 13-fold greater during visits to urologists than during visits to primary care physicians [15]. Additionally, patients with prostatitis tend to receive antimicrobials therapy in $45 \%$ of cases compared to $27 \%$ of the time for patients with no genitourinary symptoms [15]. Men with prostatitis symptoms appear to be at increased risk for persistent symptoms and for recurrent episodes. Although the pathogenesis of prostates is still being evaluated, it is common in clinical practice to see patients recurrently with acute episodes of prostatitis with a background of chronic prostatitis. These patients hence have a substantially higher cumulative probability of subsequent episodes of prostatitis [16].

\section{Pathogenesis}

The aetiology and pathophysiology of $\mathrm{CP} / \mathrm{CPPS}$ remains a mystery, although central neurological mechanisms probably play a role. Patients with PPS show no evidence of infection; they do not have urethritis, urogenital cancer, urethral stricture, or neurologic disease involving the bladder, and they do not exhibit any overt renal tract disease [17]. Hence, the exact aetiology of $\mathrm{CP} / \mathrm{CPPS}$ is unknown. The main factor that continues to be evaluated in patients with CP / CPPS is whether infection and inflammation are responsible for the clinical symptomology of these patients. The difficulty in pinpointing etiologic mechanisms and obtaining efficacious therapies is probably due to the heterogeneity of factors that contribute to CP/CPPS. Despite this complexity, most experts agree that pain is the defining feature of the condition.

The initial concept of infection and inflammation arose when True et al [18], analyzed the outcome of Prostate histopathology in 368 biopsies from 97 patients with the CP/CPPS. In these patients prostatic inflammation was detected in only $33 \%$ of patients, including $29 \%$ with mild (less than 10 leukocytes per $1 \mathrm{~mm}$. field) and $4 \%$ with moderate (between 10 and 200 ) or severe (more than 200) infiltrate. Of the 3 patients with moderate inflammation 1 had glandular, 1 periglandular and 3 multifocal or diffuse distribution of leukocytes in the interstitium. Although $33 \%$ of patients had inflammation on prostate biopsies, only $5 \%$ of 97 patients had moderate to severe inflammation. This study questioned the assocaition and role of inflammation in the pathogenesis of $\mathrm{CP} / \mathrm{CPPS}$. Despite this $\mathrm{CP} / \mathrm{CPPS}$ continues to be diagnosed on the basis of symptoms. It is diagnosed from a history of persistent genitourinary pain and an absence of other lower urinary tract pathologies. The severity of disease, its progression and treatment response can be assessed only by means of a validated symptom-scoring instrument $[19,20]$.

Patients with $\mathrm{CP} / \mathrm{CPPS}$ are diagnosed traditionally using the gold-standard four-glass test for bacterial localisation [21]. However, as this test is cumbersome to perform and hence the diagnostic efficiency may be enhanced cost effectively by a simple screening procedure, that is, the two-glass test, or by pre- and post-massage test (PPMT) [22], with PPMT able to indicate the correct diagnosis in $>96 \%$ of patients [23]. These tests use the concept of White blood cells (WBC) as a marker on inflammation. White blood cells can be found in seminal plasma and prostatic fluid of asymptomatic patients and in patients with pelvic pain [24]. Schaeffer et al [24], examined whether leukocytes and bacteria correlate with symptom severity in men with chronic prostatitis/chronic pelvic pain syndrome. In this landmark publication, 488 men were classified into the CP/CPPS criteria NIH criteria. Participants were classified as category IIIa based on WBC counts of 5 or more, or 10 or more $(5+, 10+)$ in 
the expressed prostatic secretion, or $1+$ or $5+$ either in the post-expressed prostatic secretion urine (voided urine 3 ) or semen. Uropathogens were classified as localizing if the designated bacterial species were absent in voided urine 1 and voided urine 2 but present in expressed prostatic secretion, voided urine 3 or semen, or present in expressed prostatic secretion, voided urine 3 or semen at $2 \log$ concentrations higher than at voided urine 1 or 2 . Associations between symptoms and inflammation and infection were investigated using generalized Mantel-Haenszel methods. Of all participants 50\% had urethral leukocytes and of 397 with expressed prostatic secretion samples $194(49 \%)$ and $122(31 \%)$ had 5+ or 10+ WBCs in expressed prostatic secretion, respectively. The prevalence of category IIIa ranged from $90 \%$ to $54 \%$, depending on the composite set of cut points. None of the index measures were statistically different $(\mathrm{p}>0.10)$ for selected leukocytosis subgroups. Based on prostate and semen cultures, 37 of 488 men (8\%) had at least 1 localizing uropathogen. None of the index measures were statistically different $(p>0.10)$ for selected bacterial culture subgroups. The authors thus concluded that men with chronic prostatitis routinely receive antiinflammatory and antimicrobial therapy despite leukocytes and bacterial counts which do not correlate with severity of symptoms. These findings suggest that factors other than leukocytes and bacteria also contribute to symptoms associated with chronic pelvic pain syndrome.

Based on current studies the initiator of the inflammatory process in CP / CPPS within the prostate is thought to be a local infection, chemical irritation, dysfunctional voiding, intraductal reflux, neuromuscular disturbances or an immunological process. Regardless of the triggering factor, the resultant inflammatory process causes tissue oedema and increased intra-prostatic pressure leading to local hypoxia and varied mediator-induced tissue damage. This leads to altered neurotransmission in sensory nerve fibres thereby resulting in the pain and other symptoms associated with the condition [25]. We now present each aetiology associated with CP / CPPS.

The common etiologies associated with CP / CPPS include

- $\quad 4 \mathrm{~A}$. Infection

- $\quad$ 4B. Inflammation and Autoimmunity

- $\quad 4$ C. Neurological

- 4E. Psychological

- $\quad 4 \mathrm{~F}$. Additional Conditions

\section{A. Infection}

An acute episode of prostatitis and recurrent episodes of chronic prostatitis can be caused by organisms that are commonly responsible for Urinary Tract Infections (UTI). The majority of organisms isolated within both patients groups include Escherichia coli in the community. Additionally bacteria responsible for both acute and chronic prostatitis include Pseudomonas and Streptococcus faecalis. The symptoms of CP / CPPS are identical to those of prostatic infection. Pontari et al [26], conducted a questionnaire to evaluate the demographic, behavioural, clinical and medical history characteristics of men with chronic prostatitis/chronic pelvic pain syndrome (CP/CPPS) and asymptomatic controls. In their study they analyzed the outcome of 463 men with CP/CPPS and 121 asymptomatic agematched controls. Interestingly, compared to controls, men with $\mathrm{CP} / \mathrm{CPPS}$ reported a significantly greater lifetime prevalence of nonspecific urethritis $(12 \%$ vs $4 \%, \mathrm{P}=0.008)$, cardiovascular disease $(11 \%$ vs $2 \%, \mathrm{P}=0.004)$, neurological disease $(41 \%$ vs $14 \%, \mathrm{P}<0.001)$, psychiatric conditions ( $29 \%$ vs $11 \%, \mathrm{P}<0.001)$, and haematopoietic, lymphatic or infectious 
disease $(41 \%$ vs $20 \%, \mathrm{P}<0.001)$. Hence, the outcome of this publication suggested that a range of self-reported medical conditions are associated with $\mathrm{CP} / \mathrm{CPPS}$ with a higher proportion reporting a history of nonspecific uretheritis caused due to gonorrhoeal, trichomonal and henital herpetic infections. It was also suggested that rare episodes of recurrent cystitis in young males is caused due to secondary infections of the prostatic ducts. An important factor associated with recurrent infections in $\mathrm{CP}$ is ascending urethral infection and reflux of urine into ejaculatory and prostatic ducts [27]. Bacteria can be isolated preferentially from an expressed prostatic secretion (EPS) or a post-prostatic massage urine specimen rather than from the mid-stream urine (MSU) sample or can be demonstrated on the prostatic biopsy specimen [28,29]. The concept of intraprostatic reflux was demonstrated by Kirby et al [30]. In this publication the authors injected carbon particles into the bladders of men about to undergo a transurethral resection of prostate (TURP). On histological analysis of the resected TURP specimen, carbon particles could be demonstrated which suggested a intraprostatic reflux.

Blacklock et al [31], noted that some patients with CP / CPPS had some pathogens identified in vaginal cultures of their sexual partners. Magri et al [32], evaluated 55 symptomatic patients with CP / CPPS they were subjected to segmented tests to localise Chlamydia trachomatis in first voided urine (VB1), prostatic secretions (EPS), post-massage voided (VB3) or semen specimens. Patients were divided in three treatment groups: the 'urethral involvement' group (VB1 positive, EPS/VB3/Semen negative) was treated with $500 \mathrm{mg}$ day(-1) azithromycin for 3 days. The 'prostatitis' group (VB1 negative, EPS/VB3/semen positive) with 4-week levofloxacin-azithromycin combination. A third group, 'Urethral and Prostate group' (VB1, EPS/VB3/semen positive) received both treatments in sequence. In patients prosatitis, eradication of Chlamydia trachomatis was paralleled by marked, sustained symptom improvement and by significant decrease of serum prostate-specific antigen (PSA) levels. Compared with Urethral patients, undergoing rapid regression of symptoms related to painful micturition after short-term azithromycin, U+P patients showed symptom and pathogen persistence in VB3/EPS/semen and required additional treatment with 4-week levofloxacin-azithromycin to achieve pathogen eradication, symptom regression, and decrease of PSA. The results from this publication support a causative role of Chlamydia trachomatis in CP / CPPS.

Mardh et al [33], evaluated the role of Chlamydia trachomatis in non-acute prostatitis was investigated by cultural and serological techniques in a study of 53 adult males. C. trachomatis was isolated from the urethra of only one of the 53 patients and from none of the 28 specimens of prostatic fluid from the same patients. By means of a modified microimmunofluorescent test, serum chlamydial IgG antibodies at a titre of $1 / 64$ or greater, or IgM antibodies at a titre of $1 / 8$ or greater, or both were detected in six of the patients, suggesting a recent or current chlamydial infection, while IgG or IgA antibodies at a titre of $1 / 8$ or greater were detected in the specimens of prostatic fluid from two of the 28 men studied. In the seven patients with evidence of chlamydial infection, as well as in a further 13 of the 53 patients studied, the presenting symptoms suggested non-gonococcal urethritis (NGU) rather than prostatitis. Thus in this study, C. trachomatis would appear to play a minor aetiological role, if any, in CP / CPPS.

Based on current literature and evidence, there continues to be inconsistencies in the response to antibacterial treatment and the inability to consistently isolate any pathogenic organisms in the appropriate specimens in patients with CP / CPPS. 


\section{B. Inflammation and autoimmunity}

Both acute and chronic inflammation is now thought to be associated with CP / CPPS. The core of Inflammation lies with the presence of both pro and anti-inflammatory cytokines present with the prostate in comparison to normal asymptomatic patients. The main cytokines linked with CP / CPPS are Interleukin - 8 [34], Interleukin - 10 [35] and Tumour Necrosis Factor - alpha (TNF-a) [36].

The concentration of citric acid is a significant parameter of prostate gland function [37]. Substantial amounts of citric acid are produced and stored in the gland. A decrease in its concentration is observed in cases of inflammation or cancer of the prostate gland [38]. In addition to citric acid there is now a new interest in the evaluation of polymorphonuclear (PMN) leukocytes and PMN elastase levels in patients with PC / CPPS. ZdrodowskaStefanow et al [39], evaluated PMN leukocytes , PMN elastase and citric acid concentrations in chronic prostatitis patients regardless of aetiology and in a parallel group with C trachomatis infection. In this paper the analysis of expressed prostatic secretions (EPC) of 46 patients with chronic prostatitis was evaluated for leukocyte count, PMN elastase (ELISA) and citric acid concentrations. All patients have an additional analysis for C. trachomatis infection (ligase chain reaction). Analysis confirmed increased PMN cell counts ( $\geq 10$ per high-power field) in $73.9 \%$ of patients and increased PMN elastase concentration $(<250$ $\mathrm{ng} / \mathrm{ml}$ ) in $78.3 \%$. In $44.4 \%$ of the patients the elastase concentration indicated moderate $(250-1000 \mathrm{ng} / \mathrm{ml})$ and in $55.6 \%$ acute infection $(\geq 1000 \mathrm{ng} / \mathrm{ml})$. Decreased citric acid concentration $(<18.12 \mathrm{mg} / \mathrm{ml})$ in the EPS was found in $65.2 \%$ of the men. C. trachomatis prostate infection was detected in $17.4 \%$ of the patients and all of these men had higher inflammation parameters and lower citric acid concentrations. The authors concluded that CP / CPSS associated with C. trachomatis infection were accompanied by an increase in inflammation markers and a decrease in citric acid concentration.

Autoimmunity is characterized by recognition of self by the immune system with the resulting immune response destroying or damaging normal cells and tissues. $T$ lymphocytes are principally responsible for the recognition of antigens by the immune system. CD4 T cells recognize processed peptide antigens in association with the MHC class II molecule and play a significant role in the effector function of CD8 T-cells and B-cell activation. In previous work we have shown that soluble components in normal semen can be recognized by CD4 T lymphocytes in men with CP/CPPS [40, 41]. The current concept of autoimmunity is best recognized in patients with non-specific granulomatous prostatitis (NSGP). Within this group of patients it is the HLA class II allele DRB1*1501 in Caucasian men is associated with CP/CPPS [42].

In a landmark paper evaluating the link between autoimmunity and CP / CPPS, Kouiavskaia et al [40], aimed to assess whether T cells from a group of men with CP/CPPS would recognize peptides derived from the normal self prostatic proteins prostate specific antigen (PSA) and prostatic acid phosphatase (PAP). The authors used purified CD4 T cells from the peripheral blood of 31 patients with CP/CPPS and from the buffy coat preparation of 27 normal male blood donors that were stimulated in vitro with a panel of immunogenic peptides from PSA and PAP and assayed for reactivity with the peptides by IFN- $\gamma$ ELISPOT assay. The data from this study suggested that the peptides such as $\mathrm{PAP}_{133-152}, \mathrm{PAP}_{173-192}$, PSA $_{171-190}, \mathrm{PSA}_{221-240}$ represent promiscuous epitopes able to be presented by different HLADR alleles. High level of the peptides promiscuity was supported by the results of both analysis of MHC class II allele expression by the individuals responding to the peptides in 
the IFN- $\gamma$ ELISPOT assay and analysis of the direct binding of the peptides to MHC class II molecules. In vitro functional assays showed that autoreactive $\mathrm{T}$ cells specific for the peptides are present and can be activated in the patients with CP/CPPS and normal male blood donors, identified PAP as a possible target protein for autoimmune reactivity in the patients with $\mathrm{CP} / \mathrm{CPPS}$ and demonstrated that autoimmune reactions to the immunodominant peptide $\mathrm{PAP}_{173-192}$ might be involved in the disease development. The data supported autoimmunity as a potential aetiology for CP/CPPS in some patients and suggest that immunosuppressive therapies might logically be tested in the treatment of this complex and frustrating disorder. The authors found that Peptide $\mathrm{PAP}_{173-192}$ was more frequently recognized by $\mathrm{CD} 4 \mathrm{~T}$ cells from the patients with $\mathrm{CP} / \mathrm{CPPS}$ compared to the healthy donors. Peptide reactivity was more commonly observed in cases compared to normal male blood donors for any PSA peptide or any tested peptides. This study demonstrated a strong link between autoimmunity and CP / CPPS in that CD4 T cells from patients with $\mathrm{CP} / \mathrm{CPPS}$ had a higher frequency of recognition of the self prostatic proteins PAP and PSA compared to normal male blood donors.

\section{C. Neurological}

$\mathrm{CP} / \mathrm{CPPS}$ is associated with the patient developing pain and this suggests a possible neurological link with the diagnosis. The pain perceived by these patients can be a combination of either local pain within the pelvis or more central pain. Hence, one further hypothesis in the development of CP/CPPS includes dysfunction of the nervous system that attributes to the patients symptoms. Despite attributing a strong neurological link few of the agents that have been studied in clinical trials target pain pathways directly, particularly those in the central nervous system (CNS). Recent animal model studies on retrograde labelling of the prostate and pelvic floor indicates that there are double labelled cells in the dorsal root ganglion in the lumbar and sacral cord [42]. Patients with CPPS are thought to have an altered sensation of the perineum in comparison to control patients without $\mathrm{CP} / \mathrm{CPPS}$. The mechanism of this 'altered' innervations is poorly understood and is thought to be related to reflex sympathetic dystrophy of the perineum and pelvic floor [43-45].

\section{E. Psychological}

Psychological stress is also commonly associated with the exacerbation of symptoms related to CP/CPPS. The initial evidence of a strong psychological link was after Wallner et al [46], collected data from 703 men enrolled in the Flint Men's Health Study, a population-based health study of African American men. Participants were interviewed about their health history and lifestyle factors, such as physical activity. They also answered questions about stress and emotional health. In this study poor emotional health, high levels of stress (as perceived by study participants), and a lack of social support were associated with a history of CP. The findings were consistent with a previous study by Collins et al [47], which also reconfirmed that patients with severe stress at work or home were 1.2 and 1.5 times more likely to report $\mathrm{CP}$, respectively, than those whose lives were relatively stress-free.

Ullrich et al [48], associated stress to be an important factor responsible for the development of CP/CPPS. In this study, 200 men were interviewed about the level of stress and degree of pain intensity by telephone a month after the men were diagnosed with $\mathrm{CP}$ and then again three, six, and 12 months later. This publication concluded that the men with more perceived stress during the six months following diagnosis were in more pain after a year than those who experienced less stress. Despite the limitations of the study, such as the lack 
of health data on participants prior to diagnosis, the paper concluded that treatment in patients with CP / CPPS should include stress management techniques.

4F. Additional health conditions

Additional health conditions associated with CP / CPPS include - Irritable bowel syndrome, Fibromyalgia and chronic fatigue syndrome.

\section{Diagnosis}

There is no gold standard for diagnostic testing for the CPPS [49]. The 4-glass or 2-glass test may provide information on prostatic inflammation (e.g., the number of white cells per high-power field), but this finding is not helpful in the diagnosis or management of the condition. Among men with presumed chronic pelvic pain syndrome and no history of urinary tract infection, up to $8 \%$ have been found to have positive prostatic localization cultures, but these findings have also been reported in a similar percentage of asymptomatic men [50].

The current EAU 2008 guidelines highlight that CP/CPPS is more of a symptomatic diagnosis. To facilitate in the diagnosis the following an initial sterile pre-massage urine (voided bladder urine-2 [VB2]) is collected, patient with CP/CPPS shows less than 10,000 colony-forming units of uropathogenic bacteria in expressed prostatic secretions (EPS) and insignificant numbers of leucocytes or bacterial growth in ejaculate. Diagnostic efficiency may be enhanced cost-effectively by a simple screening procedure, i.e. the two-glass test or pre-post-massage test (PPMT) [49]. In an extensive analysis of both tests, PPMT was able to indicate the correct diagnosis in more than $96 \%$ of patients [50].

Additional tests performed to facilitate diagnosis include a flowrate studies, urodynamic assessments and a transrectal ultrasound to exclude an obstructed seminal vesicle. A transrectal ultrasound is indicated in patients with CP/CPPS and painful ejaculation. In these patients a transrectal ultrasonography may reveal enlargement of the seminal vesicle caused by obstruction of the ejaculatory duct; such an obstruction may be associated with or exacerbate the chronic pelvic pain syndrome. Isolated case reports suggest that the correction of the obstruction may relieve pain, although this cannot be proved because of a lack of data [51]. A urodynamic assessment can be performed when patients have concomitant lower urinary tract symptoms that are refractory to treatment.

To assess the accurate symptomology at the time of diagnosis it is essential for patients tom complete the The NIH Chronic Prostatitis Symptom Index. This 9 item, self-administered tool leads to the development of a score between is 0 to 43 points [52]. A summary of the current investigations from our department based on current European Association of Urology guidelines summarized in Figure 1.

\section{Treatment}

The treatment of CP/CPPS continues to be challenging. We divide the Urological treatment into Medical and Surgical categories.

\section{A. Urological medical treatment}

Effective treatment for the $\mathrm{CP} / \mathrm{CPPS}$ remains uncertain. Factors complicating the management of this condition include its probably multifactorial pathogenesis, lack of a gold standard for diagnostic testing, and the methodological limitations of many treatment 


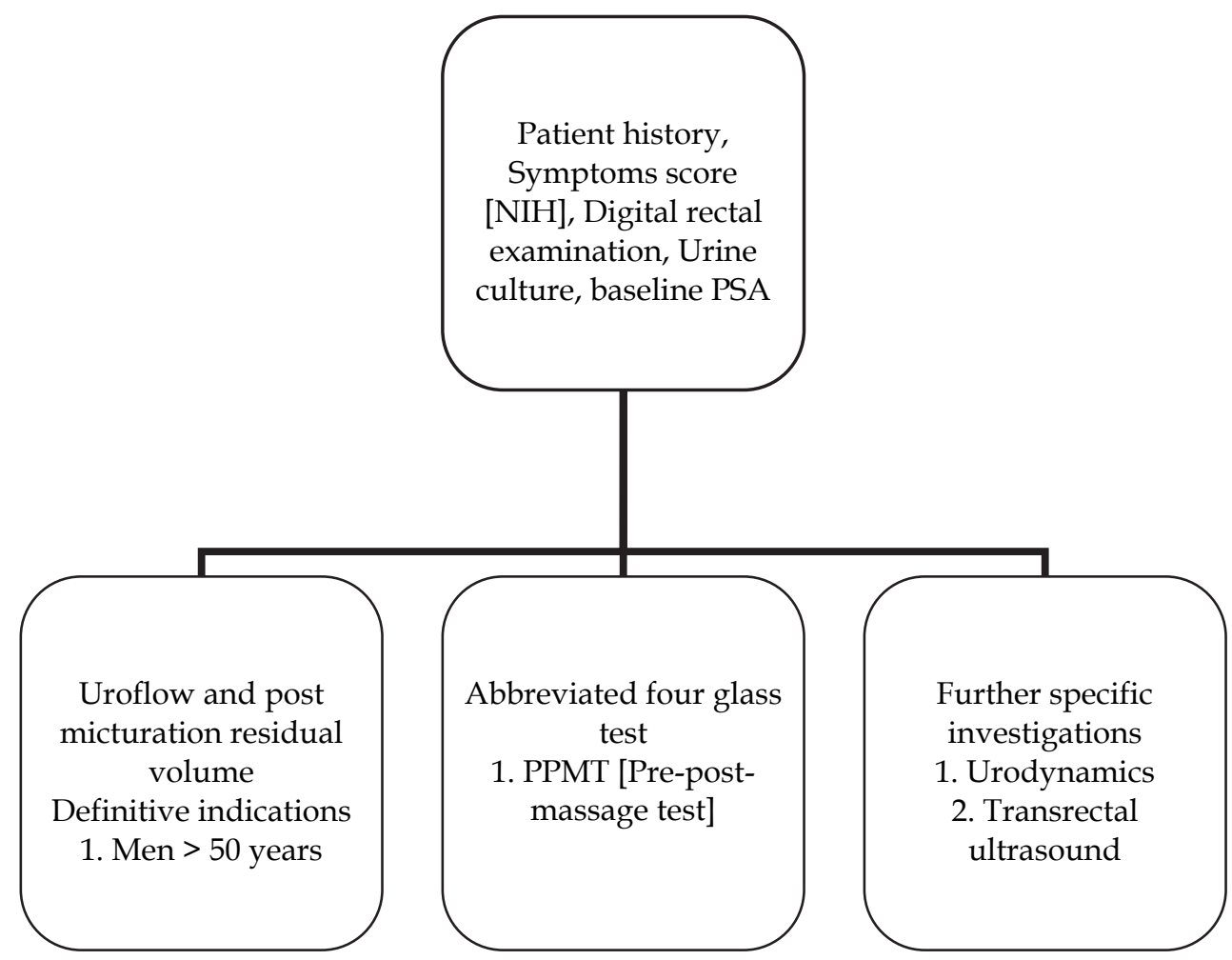

Fig. 1. Our departments guidelines for the initial investigating patients with CP/CPPS.

studies. Most current treatment strategies focus on symptomatic relief. Despite of numerous advocated strategies and new drugs being developed, the US Preventive Services Task Force system best summarizes current treatments for CP/CPSS as grade 1 which is defined as "drug therapy where current evidence is insufficient to assess the balance of benefits and harms of the service. Evidence is lacking, of poor quality, or conflicting, and the balance of benefits and harms cannot be determined."

The predominant medical treatment of drugs include:-

1. Antibiotics

2. Alpha blockers

3. Anti-inflammatories

4. 5 a reductase inhibitors

5. Pentosulphan Polyphosphate

6. Additional therapies [Physical therapy, Myofascial and trigger point therapy]

The current mechanism of action and evidence to support the above mentioned treatment is summarized in Table 2.

The Urological Surgery Treatment in patients with CP/CPPS include

1. Prostatic Massage

2. Transurethral Microwave therapy

3. Transurethral resection of prostate 


\begin{tabular}{|c|c|c|c|}
\hline Drug & Mechanism of action & $\begin{array}{c}\text { Evidence for } \\
\text { treatment/Recommended } \\
\text { agents }\end{array}$ & Side effects \\
\hline 1. Antibiotics & $\begin{array}{l}\text { Reduces and cures } \\
\text { infections. This further } \\
\text { reduces inflammation } \\
\text { and hence improves } \\
\text { symptoms of } \\
\text { CP/CPPS. }\end{array}$ & $\begin{array}{l}\text { A. Levofloxacin in } 80 \text { patients } \\
\text { for } 6 \text { weeks. Outcome - } 6 \\
\text { point decrease in NIH } \\
\text { symptoms [53] } \\
\text { B. Ciprofloxacin in } 196 \\
\text { patients for 4-6 weeks. } \\
\text { Outcome - Significant } \\
\text { symptomatic improvement } \\
\text { [54] }\end{array}$ & $\begin{array}{l}\text { A. Side effects of } \\
\text { fluroquinolones } \\
\text { including central } \\
\text { nervous system } \\
\text { (CNS) toxicity, } \\
\text { phototoxicity, } \\
\text { cardiotoxicity, } \\
\text { arthropathy, and } \\
\text { tendon toxicity. } \\
\text { B. RCTs have } \\
\text { failed to show } \\
\text { significant } \\
\text { beneficial effects of } \\
\text { antibiotics } \\
\text { compared to } \\
\text { placebo in patients } \\
\text { who have already } \\
\text { failed antibiotic } \\
\text { treatment }\end{array}$ \\
\hline 2. Alpha blockers & $\begin{array}{l}\text { Inhibit neurological } \\
\text { activation induced by } \\
\text { sympathetic } \\
\text { overactivation }\end{array}$ & $\begin{array}{l}\text { A. Meta-analysis of treatment } \\
\text { with Alpha blockers in men } \\
\text { with CP/CPPS showed } \\
\text { significant reduction in } \\
\text { symptoms over a duration of } \\
3 \text { months [55]. }\end{array}$ & $\begin{array}{l}\text { Adverse effects of } \\
\text { alpha-blockers } \\
\text { include dizziness, } \\
\text { fatigue, } \\
\text { hypotension and } \\
\text { decreased ejaculate } \\
\text { volume }\end{array}$ \\
\hline $\begin{array}{l}\text { 3. Anti- } \\
\text { inflammatories }\end{array}$ & $\begin{array}{l}\text { Reduce systemic or } \\
\text { prostatic inflammation, } \\
\text { autoimmunity, CNS } \\
\text { transmission of pain } \\
\text { signals, and central } \\
\text { sensitization }\end{array}$ & $\begin{array}{l}\text { A. Main symptom of } \\
\text { CP/CPPS is pain. Hence, it is } \\
\text { very important to control this } \\
\text { symptom. } \\
\text { B. Tricyclic Antidepressants } \\
\text { are widely used for pain and } \\
\text { act by inhibiting central } \\
\text { neuronal reuptake of } \\
\text { Norepinephrine and } \\
\text { Serotonin. Both substances } \\
\text { linked to pain. } \\
\text { C. Current medication } \\
\text { recommenced includes - } \\
\text { Gabapentin, Pregabalin and } \\
\text { Amitriptyline } \\
\text { D. COX } 2 \text { inhibitors are now } \\
\text { being investigated as these } \\
\text { drugs regulate prostaglandin } \\
\text { production. In an RCT of the } \\
\text { COX2 inhibitor rofecoxib, the } \\
\text { NIH-CPSI total and pain } \\
\text { scores showed improvement } \\
\text { in the rofecoxib group, but the } \\
\text { difference between rofecoxib } \\
\text { and placebo was not } \\
\text { statistically significant [56]. }\end{array}$ & $\begin{array}{l}\text { Adverse effects of } \\
\text { Tricyclic include } \\
\text { dry mouth, dry } \\
\text { nose, and increased } \\
\text { body temperature. } \\
\text { Other side effects } \\
\text { may include } \\
\text { drowsiness, } \\
\text { anxiety, akathisia, , } \\
\text { tachycardia. } \\
\text { Twitching, } \\
\text { hallucinations, } \\
\text { delirium and coma } \\
\text { are also some of the } \\
\text { toxic effects caused } \\
\text { by overdose. } \\
\text { Rhabdomyolysis or } \\
\text { muscle breakdown } \\
\text { has been rarely } \\
\text { reported. }\end{array}$ \\
\hline
\end{tabular}




\begin{tabular}{|c|c|c|c|}
\hline Drug & Mechanism of action & $\begin{array}{c}\text { Evidence for } \\
\text { treatment/Recommended } \\
\text { agents }\end{array}$ & Side effects \\
\hline $\begin{array}{l}4.5 \text { a reductase } \\
\text { inhibitors }\end{array}$ & $\begin{array}{l}\text { Reduction in prostatic } \\
\text { volume }\end{array}$ & $\begin{array}{l}\text { A. One randomized, placebo- } \\
\text { controlled trial of Finasteride } \\
\text { showed that scores on the } \\
\text { Prostatitis Symptom Severity } \\
\text { Index and the International } \\
\text { Prostatitis Symptom Survey } \\
\text { decreased significantly after } 1 \\
\text { year of treatment, but pain } \\
\text { scores did not change } \\
\text { significantly [57]. } \\
\text { B. Response rates at } 6 \text { months } \\
\text { (defined as an improvement } \\
\text { of more than } 25 \% \text { in scores on } \\
\text { the NIH Chronic Prostatitis } \\
\text { Symptom Index) were not } \\
\text { significantly better for } \\
\text { Finasteride than for placebo } \\
\text { (33\% vs. 16\%) [58]. }\end{array}$ & $\begin{array}{l}\text { Adverse effects of } 5 \\
\text { a reductase } \\
\text { inhibitors include } \\
\text { impotence, } \\
\text { decreased libido, } \\
\text { and decreased } \\
\text { ejaculate volume. } \\
\text { Rare side effects } \\
\text { include breast } \\
\text { tenderness and } \\
\text { enlargement. }\end{array}$ \\
\hline $\begin{array}{l}\text { 5. Pentosulphan } \\
\text { Polyphosphate }\end{array}$ & $\begin{array}{l}\text { Replenish the } \\
\text { glycosaminoglycan } \\
\text { layer of the bladder, } \\
\text { stabilize prostatic } \\
\text { stromal mast cells }\end{array}$ & $\begin{array}{l}\mathrm{CP} / \mathrm{CPPS} \text { is thought to be } \\
\text { related conditions, and } \\
\text { Pentosan Polysulfate has been } \\
\text { tested in an RCT for CP/CPPS. } \\
\text { The results showed some } \\
\text { clinical benefit in the } \\
\text { treatment arm, but the change } \\
\text { in total NIH-CPSI score was } \\
\text { not statistically significant } \\
\text { [59]. }\end{array}$ & $\begin{array}{l}\text { Pentosan } \\
\text { Polysulfate has } \\
\text { minimal side effects } \\
\text { and is well } \\
\text { tolerated. }\end{array}$ \\
\hline $\begin{array}{l}\text { 6. Additional } \\
\text { therapies } \\
\text { [Physical } \\
\text { therapy, } \\
\text { Myofascial and } \\
\text { trigger point } \\
\text { therapy }\end{array}$ & $\begin{array}{l}\text { Reduce pelvic floor } \\
\text { muscle dysfunction }\end{array}$ & $\begin{array}{l}\text { A. Physical therapy, } \\
\text { Myofascial therapy and } \\
\text { trigger point therapy reduce } \\
\text { symptoms related to } \\
\mathrm{CP} / \mathrm{CPPS} \text {. } \\
\text { B. A recent study has } \\
\text { demonstrated a statistically } \\
\text { significant improvement in } \\
\text { symptoms in the patients } \\
\text { receiving myofascial therapy } \\
\text { for CP/CPPS in comparison } \\
\text { to the pharmacological } \\
\text { medication mention in } \\
\text { category } 1-3 \text {. }\end{array}$ & None reported \\
\hline
\end{tabular}

Table 2. Urological Medical Treatment of CP/CPPS. 


\section{B. Urological Surgery Treatment}

The latter two treatments have side effects including reterograde ejaculation and erectile dysfunction. These must be highlighted to patients being offered Urological Surgery for medically refractory $\mathrm{CP} / \mathrm{CPPS}$ which continues to be a clinically challenging category of patients to manage.

\section{Prostate Massage}

The rationale of this procedure is to try to expel dense prostatic secretion and/or to force an obstructed outlet duct. In order to avoid damage to the integrity of a prostatic acinus which could lead to worsening of the inflammation, it should be done with care, and in my opinion, not before the patient has had hot baths and drugs for a couple of days. It seems very helpful in those patients in whom TRUS has shown a sectorial oedema in the prostate. In my experience, patients with massive calcifications in the veru-region are rarely helped by this manoeuvre; this seems understandable, as those calcifications cannot be removed by massage, but, on the contrary, manipulation can traumatize this area and worsen the situation. I see my patients 2-3 times a week for a total of about 6-8 sessions.

\section{Transurethral Microwave therapy}

Transurethral microwave thermotherapy, which is widely available, can achieve temperatures of more than $45^{\circ} \mathrm{C}$ within prostatic tissue. One small randomized trial (20 patients) suggested that transurethral microwave thermotherapy significantly improved the quality of life at 3 months, as compared with sham treatment [61]; four patients reported transient adverse effects, including hematuria, urinary tract infection, impotence, urinary retention, urinary incontinence, and premature ejaculation, but whether these patients received active or sham treatment was not stated.

\section{Transurethral Resection of Prostate}

Transurethral resection of the prostate (TURP) is advocated for CP/CPPS based on a few anecdotal experiences, but there are absolutely no reliable data or experiences to substantiate a treatment effect [62]. Patient with significant lower urinary tract symptoms with a background of $\mathrm{CP} / \mathrm{CPPS}$ may benefit from this therapy.

\section{Conclusion}

Chronic Prostatitis / Chronic Pelvic pain syndrome continues to be a challenging clinical entity for urologists. A thorough clinical evaluation and organizing appropriate clinical investigations are essential to establish a potentially treatable cause, although this is not found in all patients. With new avenues of autoimmunity and inflammation being explored as a strong link in the pathogenesis of CP/CPPS, we envisage that this may well direct future treatment strategies. However, based on current clinical practice a combination of treatment trial including newer biomarkers, genomic, immunological, imaging studies, epidemiologic and symptom-based assessments, will maximize the ability to identify an effective treatment strategy in the future.

\section{References}

[1] Schaeffer, AJ; Datta, NS; Fowler Jr, JE; Krieger, JN; Litwin, MS; Nadler, RB; Nickel, JC; Pontari, MA et al. (2002). "Overview summary statement. Diagnosis and 
management of chronic prostatitis/chronic pelvic pain syndrome (CP/CPPS)". Urology 60 (6 Suppl): 1-4.

[2] Nickel JC, Weidner W. Chronic prostatitis: current concepts and antimicrobial therapy. Infect Urol 2000;13:S22-8.

[3] Krieger JN, Nyberg L, Jr, Nickel JC. NIH consensus definition and classification of prostatitis.JAMA.1999;282:236-237

[4] Schaeffer AJ. Clinical practice. Chronic prostatitis and the chronic pelvic pain syndrome. N Engl J Med. 2006;355:1690-1698

[5] De la Rosette JJ, Hubregtse MR, Meuleman EJ, Stolk-Engelaar MV, Debruyne FM. Diagnosis and treatment of 409 patients with prostatitis syndromes. Urology. 1993 Apr;41(4):301-7

[6] Kaplan SA, Lee JY, Meehan AG, Kusek JW; MTOPS Research Group. Long-Term Treatment With Finasteride Improves Clinical Progression of Benign Prostatic Hyperplasia in Men With an Enlarged Versus a Smaller Prostate: Data From the MTOPS Trial. J Urol. 2011 Apr;185(4):1369-73

[7] Roberts RO, Lieber MM, Rhodes T, Girman CJ, Bostwick DJ, Jacobsen SJ. Prevalence of a physician-assigned diagnosis of prostatitis: The Olmstead County study of urinary symptoms and health status among men. Urology. 1998;51:578-84.

[8] Collins MM, Meigs JB, Barry MJ, Walker Corkery E, Giovannucci E, Kawachi I. Prevalence and correlates of prostatitis in the health professionals follow-up study cohort. J Urol. 2002;167:1363-6.

[9] Collins MM, Stafford RS, O'Leary MP, Barry MJ. How common is prostatitis? A national survey of physician visits. J Urol. 1998;159:1224-8

[10] Wenninger K, Heiman J, Rothman I, Berguis JP, Berger BE. Sickness impact on chronic nonbacterial prostatitis and its correlates. J Urol. 1996;155:965-8.

[11] Lobel B, Rodriguez A. Chronic prostatitis: What we know, what we don't know and what we should do! World J Urol. 2003;21:57-63.

[12] Stamey TA. Periurethral or perineal bacteria in urinary tract infections? JAMA. $1981 ; 245: 127-8$

[13] Krieger JN, Lee SW, Jeon J, Cheah PY, Liong ML, Riley DE. Epidemiology of prostatitis. Int J Antimicrob Agents. 2008 Feb;31 Suppl 1:S85-90

[14] Nickel JC, Downey J, Hunter D, Clark J. Prevalence of prostatitis-like symptoms in a population based study using the National Institutes of Health chronic prostatitis symptom index. J Urol. 2001;165:842-5

[15] Collins MM, Stafford RS, O'Leary MP, Barry MJ. How common is prostatitis? A national survey of physician visits. J Urol. 1998;159:1224-8.

[16] Turner JA, Ciol MA, Von Korff M, Berger R. Prognosis of patients with new prostatitis/pelvic pain syndrome episodes. J Urol. 2004;172:538-41

[17] Nickel JC, Weidner W. Chronic prostatitis: current concepts and antimicrobial therapy. Infect Urol 2000;13:S22-8.

[18] True LD, Berger RE, Rothman I, Ross SO, Krieger JN. Prostate histopathology and the chronic prostatitis/chronic pelvic pain syndrome: a prospective biopsy study. J Urol. 1999 Dec;162(6):2014-8

[19] Barry MJ, Fowler Jr FJ, O'Leary MP, et al. The American Urological Association symptom index for benign prostatic hyperplasia. The Measurement Committee of the American Urological Association. J Urol 1992;148:1549-57, discussion 1564. 
[20] Nickel JC. Effective office management of chronic prostatitis. Urol Clin North Am 1998;25:677-84.

[21] Meares EM, Stamey TA. Bacteriologic localization patterns in bacterial prostatitis and urethritis. Invest Urol 1968;5:492-518.

[22] Nickel JC. The pre and post massage test (PPMT): a simple screen for prostatitis. Tech Urol 1997;3:38-43.

[23] Nickel JC, Shoskes D, Wang Y, et al. How does the pre-massage and postmassage 2glass test compare to the Meares-Stamey 4-glass test in men with chronic prostatitis/chronic pelvic pain syndrome?J Urol 2006;176:119-24.

[24] Schaeffer AJ, Knauss JS, Landis JR, Propert KJ, Alexander RB, Litwin MS, Nickel JC, O'Leary MP, Nadler RB, Pontari MA, Shoskes DA, Zeitlin SI, Fowler JE Jr, Mazurick CA, Kusek JW, Nyberg LM; Chronic Prostatitis Collaborative Research Network Study Group. Leukocyte and bacterial counts do not correlate with severity of symptoms in men with chronic prostatitis: the National Institutes of Health Chronic Prostatitis Cohort Study. J Urol. 2002 Sep;168(3):1048-53.

[25] Vaidyanathan R, Mishra VC. Chronic prostatitis: Current concepts. Indian J Urol. 2008 Jan;24(1):22-7.

[26] Bartoletti R, Mondaini N, Pavone C, Dinelli N, Prezioso D. Introduction to chronic prostatitis and chronic pelvic pain syndrome (CP/CPPS). Arch Ital Urol Androl. 2007 Jun;79(2):55-7

[27] Nickel JC, Bruce AW, Reid G. Pathogenesis, diagnosis and treatment of the prostatitis syndromes. In: Krane RJ, Siroky MB, editors. Clinical urology. Philadelphia: Lippincott; 1994. p. 925.

[28] Berger RE, Krieger JN, Rothman I, Muller CH, Hillier SL. Bacteria in the prostate tissue of men withidiopathic prostatic inflammation. J Urol. 1997;157:863-5.

[29] Nickel JC, Costerton JW. Bacterial localization in antibiotic-refractory chronic bacterial prostatitis. Prostate. 1993;23:107-14.

[30] Kirby RS, Lowe D, Bultitude MI, Shuttleworth KE. Intra-prostatic urinary reflux: an aetiological factor in abacterial prostatitis. Br J Urol. 1982 Dec;54(6):729-31

[31] Blacklock NJ. Anatomical factors in prostatitis. Br J Urol.1974 Feb;46(1):47-54

[32] Magri V, Marras E, Skerk V, Markotić A, Restelli A, Garlaschi MC, Perletti G. Eradication of Chlamydia trachomatis parallels symptom regression in chronibacterial prostatitis patients treated with a fluoroquinolone-macrolide combination.Andrologia. 2010 Dec;42(6):366-75

[33] Mårdh PA, Ripa KT, Colleen S, Treharne JD, Darougar S. Role of Chlamydia trachomatis in non-acute prostatitis. Br J Vener Dis. 1978 Oct;54(5):330-4.

[34] Hochreiter WW, Nadler RB, Koch AE, Campbell PL, Ludwig M, Weidner W, Schaeffer AJ. Evaluation of the cytokines interleukin 8 and epithelial neutrophil activating peptide 78 as indicators of inflammation in prostatic secretions. Urology. 2000 Dec 20;56(6):1025-9.

[35] Miller LJ, Fischer KA, Goralnick SJ, Litt M, Burleson JA, Albertsen P, Kreutzer DL. Interleukin-10 levels in seminal plasma: implications for chronic prostatitis-chronic pelvic pain syndrome. J Urol. 2002 Feb;167(2 Pt 1):753-6.

[36] Nadler RB, Koch AE, Calhoun EA, Campbell PL, Pruden DL, Bennett CL, Yarnold PR, Schaeffer AJ. IL-1beta and TNF-alpha in prostatic secretions are indicators in the evaluation of men with chronic prostatitis. J Urol. 2000 Jul;164(1):214-8. 
[37] Kavanagh J. P., Darby C. and Costello C. B. (1982): The response of seven prostatic fluid components to prostatic disease. Int. J. Androl., 5, 487-496

[38] Kammer H., Scheit K. H., Weidner W. and Cooper T. G. (1991): The evaluation of markers of prostatic function. Urol. Res., 19, 343-347

[39] Zdrodowska-Stefanow B, Ostaszewska-Puchalska I, Badyda J, Galewska Z. The evaluation of markers of prostatic inflammation and function of the prostate gland in patients with chronic prostatitis. Arch Immunol Ther Exp (Warsz). 2008 JulAug;56(4):277-82. Epub 2008 Jul 29.

[40] Kouiavskaia DV, Southwood S, Berard CA, Klyushnenkova EN, Alexander RB. T-cell recognition of prostatic peptides in men with chronic prostatitis/chronic pelvic pain syndrome. J Urol. 2009 Nov;182(5):2483-9

[41] Alexander RB, Brady F, Ponniah S. Autoimmune prostatitis: Evidence of T cell reactivity with normal prostatic proteins. Urology. 1997;50:893.

[42] Yang CC, Lee JC, Kromm BG, Ciol MA, Berger RE. Pain sensitization in male chronic pelvic pain syndrome: why are symptoms so difficult to treat? J Urol. 2003 Sep;170(3):823-6; discussion 826-7.

[43] Andersen JT. Treatment of prostatodynia. In: Nickel JC (ed). Textbook of Prostatitis. London: ISIS Medical Media Ltd. 1999; pp. 357-364.

[44] Egan KJ, Krieger JL. Chronic abacterial prostatitis-a urological chronic pain syndrome? Pain 1997Feb;69(3):213-8.

[45] Osborn DE, George NJ, Rao PN, Barnard RJ, Reading C, Marklow C, Blacklock NJ. Prostatodynia- physiological characteristics and rational management with muscle relaxants. Br J Urol 1981 Dec;53(6):621-3.

[46] Wallner LP, Clemens JQ, Sarma AV. Prevalence of and Risk Factors for Prostatitis in African American Men: The Flint Men's Health Study. Prostate 2009;69:24-32

[47] Collins MM, Meigs JB, Barry MJ, et al. Prevalence and Correlates of Prostatitis in the Health Professionals Follow-Up Study Cohort. Journal of Urology 2002;167:136366.

[48] Ullrich PM, Turner JA, Ciol M, Berger R. Stress Is Associated with Subsequent Pain and Disability Among Men with Nonbacterial Prostatitis/Pelvic Pain. Annals of Behavioral Medicine 2005;30:112-18.

[49] McNaughton Collins M, MacDonald R, Wilt TJ. Diagnosis and treatment of chronic abacterial prostatitis: a systematic review. Ann Intern Med 2000;133:367-81.

[50] Nickel JC, Alexander RB, Schaeffer AJ, Landis JR, Knauss JS, Propert KJ. Leukocytes and bacteria in men with chronic prostatitis/chronic pelvic pain syndrome compared to asymptomatic controls. J Urol 2003;170:818-22.

[51] Nadler RB, Rubenstein JN. Laparoscopic excision of a seminal vesicle for the chronic pelvic pain syndrome. J Urol 2001;166:2293-4.

[52] Litwin MS, McNaughton-Collins M, Fowler FJ Jr, et al. The National Institutes of Health chronic prostatitis symptom index: development and validation of a new outcome measure. J Urol 1999;162:369-75.

[53.Nickel JC, Downey J, Clark J, et al. Levofloxacin for chronic prostatitis/chronic pelvic pain syndrome in men: a randomized placebo-controlled multicenter trial. Urology 2003;62:614-7. 
[54] Alexander RB, Propert KJ, Schaeffer AJ, et al. Ciprofloxacin or tamsulosin in men with chronic prostatitis/chronic pelvic pain syndrome: a randomized, double-blind trial. Ann Intern Med 2004;141:581-9.

[55] Yang G, Wei Q, Li H, Yang Y, Zhang S, Dong Q. The effect of alpha-adrenergic antagonists in chronic prostatitis/chronic pelvic pain syndrome: a meta-analysis of randomized controlled trials. J Androl. 2006 Nov-Dec;27(6):847-52. Epub 2006 Jul 26.

[56] Zeng $X$, et al. Clinical evaluation of celecoxib in treating type IIIA chronic prostatitis [Chinese] Zhonghua Nan Ke Xue. 2004;10:278-281

[57] McNaughton Collins M, MacDonald R, Wilt TJ. Diagnosis and treatment of chronic abacterial prostatitis: a systematic review. Ann Intern Med 2000;133:367-81.

[58] Nickel JC, Downey J, Pontari MA, Shoskes DA, Zeitlin SI. A randomized placebocontrolled multicentre study to evaluate the safety and efficacy of finasteride for male chronic pelvic pain syndrome (category IIIA chronic nonbacterial prostatitis). BJU Int 2004;93:991-5.

[59] Nickel JC, et al. Pentosan polysulfate sodium therapy for men with chronic pelvic pain syndrome: a multicenter, randomized, placebo controlled study. J Urol. 2005;173:1252-1255.

[60] FitzGerald MPS. Randomized multicenter feasibility trial of myofascial physical therapy for the treatment of urological chronic pelvic pain syndromes. J Urol. 2009;182:570580

[61] McNaughton Collins M, MacDonald R, Wilt TJ. Diagnosis and treatment of chronic abacterial prostatitis: a systematic review. Ann Intern Med 2000;133:367-81.

[62] Kaplan SA, Te AE, Jacobs BZ. Urodynamic evidence of vesical neck obstruction in men with misdiagnosed chronic nonbacterial prostatitis and the therapeutic role of endoscopic incision of the bladder neck. J Urol. 1994;152:2063-5 


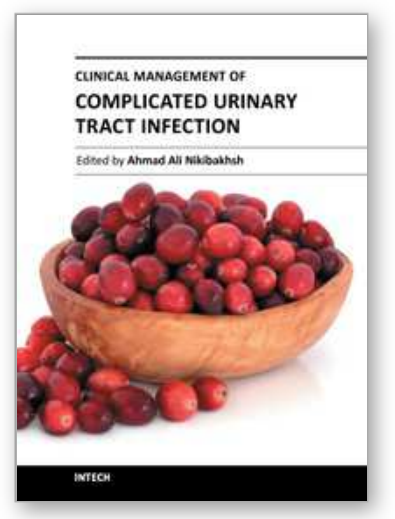

\author{
Clinical Management of Complicated Urinary Tract Infection \\ Edited by Dr. Ahmad Nikibakhsh
}

ISBN 978-953-307-393-4

Hard cover, 294 pages

Publisher InTech

Published online 06, September, 2011

Published in print edition September, 2011

Complicated urinary tract infections (cUTIs) are a major cause of hospital admissions and are associated with significant morbidity and health care costs. Knowledge of baseline risk of urinary tract infection can help clinicians make informed diagnostic and therapeutic decisions. Prevalence rates of UTI vary by age, gender, race, and other predisposing risk factors. In this regard, this book provides comprehensive information on etiology, epidemiology, immunology, pathology, pathogenic mechanisms, symptomatology, investigation and management of urinary tract infection. Chapters cover common problems in urinary tract infection and put emphasis on the importance of making a correct clinical decision and choosing the appropriate therapeutic approach. Topics are organized to address all of the major complicated conditions frequently seen in urinary tract infection. The authors have paid particular attention to urological problems like the outcome of patients with vesicoureteric reflux, the factors affecting renal scarring, obstructive uropathy, voiding dysfunction and catheter associated problems. This book will be indispensable for all professionals involved in the medical care of patients with urinary tract infection.

\title{
How to reference
}

In order to correctly reference this scholarly work, feel free to copy and paste the following:

Nikhil Vasdev and Andrew C Thorpe (2011). Chronic Prostatitis / Chronic Pelvic Pain Syndrome, Clinical Management of Complicated Urinary Tract Infection, Dr. Ahmad Nikibakhsh (Ed.), ISBN: 978-953-307-393-4, InTech, Available from: http://www.intechopen.com/books/clinical-management-of-complicated-urinary-tractinfection/chronic-prostatitis-chronic-pelvic-pain-syndrome

\section{INTECH}

open science | open minds

\section{InTech Europe}

University Campus STeP Ri

Slavka Krautzeka 83/A

51000 Rijeka, Croatia

Phone: +385 (51) 770447

Fax: +385 (51) 686166

www.intechopen.com

\section{InTech China}

Unit 405, Office Block, Hotel Equatorial Shanghai

No.65, Yan An Road (West), Shanghai, 200040, China 中国上海市延安西路65号上海国际贵都大饭店办公楼 405 单元

Phone: +86-21-62489820

Fax: +86-21-62489821 
(C) 2011 The Author(s). Licensee IntechOpen. This chapter is distributed under the terms of the Creative Commons Attribution-NonCommercialShareAlike-3.0 License, which permits use, distribution and reproduction for non-commercial purposes, provided the original is properly cited and derivative works building on this content are distributed under the same license. 